\title{
Determinants of Market Reactions to the Disclosure of Directors and Officers Insurance Purchases - Evidence from Taiwan
}

\author{
Yenyu (Rebecca) Huang* \\ Department of Tourism and Leisure Management, St. John's University, Taiwan
}

*Corresponding author: Yenyu (Rebecca) Huang, Department of Tourism and Leisure Management, St. John's University, New Taipei City, Taiwan.

Received Date: December 02, 2019

Published Date: December 09, 2019

\begin{abstract}
This paper examines the market reaction to a sample of 623 directors' and officers' insurance first purchase announced from $2002-2010$ in Taiwan. This paper documents an average abnormal return of about -0.870 percent over a 2-day announcement window. Instead viewing such insurance necessary to attract and maintain competent directors and officers, shareholders view such insurance to have adverse effects on their wealth. In addition, this paper finds that more negative returns are associated with firms with more directors' compensations (option), firms whose stocks are more volatile, and firms with higher litigation risks. The result of this paper support shareholder protection hypothesis, compensation package hypothesis, signalling hypothesis, and litigation risk hypothesis. The contribution of this paper is to indicate that disclosure of the purchase of D\&O insurance, in addition to the characteristics of the firm's corporate governance, are critical in determining the market reaction to D\&O insurance purchase by firms. It indicates that detailed information in the D\&O insurance purchase disclosure affect investors' evaluation future company prospects as well as the risk/uncertainty of achieving them. Results of this paper also provide the evidence that mandatory disclosure of the details of D\&O insurance purchase policy, as is required in countries like UK and Canada, is justified and valuable.
\end{abstract}

Keywords: Directors and officers insurance; Shareholder litigation; Board compensation; Corporate governance; Event study

\section{Introduction}

The purpose of this paper is to assess whether the purchase and detailed disclosures of insured firms' D\&O policies are valued from investors' (or shareholders') standpoints. Specifically, this paper examines the stock price reaction to first purchase announcement by using event study method and whether market reactions are determined by the characteristics of the firm's corporate governance. Following a lot of well-publicized accounting scandals (e.g., Enron, Adelphia, and WorldCom), much of the blame has fallen on failings of the outside auditor. In order to inform investors and other capital market participants' understanding of outside auditor's assessment of the quality of the firm's financial reporting, the US SEC issued revised auditor independence requirements in November 2000 and mandated registrants to disclose both audit fees and non-audit fees paid to auditors. However, another potential gatekeeper, the directors' and officers' (D\&O) insurer, has received little notice. The primary role of the D\&O insurer is to assume an insured's risk of shareholder litigation. Because the risk of shareholder litigation is related to the quality of a firm's corporate governance, D\&O insurers use corporate governance assessments to screen prospective insureds, to quantify the risk of litigation loss and at last to determine an appropriate premium for individual firm. Simply stated, insureds with worse corporate governance are postulated to pay higher D\&O premiums than insureds with better corporate governance.

Therefore, investors and other capital market participants should be able to be better informed about whether firm's corporate governance is good or not by examining an insured firm's premiums, limits, and retentions. Unfortunately, U.S. securities regulators do not require registrants to disclose the details of D\&O insurance decisions. In addition [1], find a significant negative relation between the three-year post IPO stock price performance and the D\&O insurance purchases in conjunction with the IPO. They conclude that since D\&O insurance decisions are not required to disclose and managers' incentive to exploit their information 
advantages to increase their wealth is provoked. Only in few countries, securities commissions require registrants to disclose the details of their D\&O policies. This is the reason of this paper to select Taiwan firms to examine this issue because Taiwan firms are not required by Taiwan regulators but voluntarily disclosing whether they purchase D\&O insurance. It provides this paper a special opportunity to study market reactions to the disclosure of directors' and officers' insurance first purchase by using the event study method.

Because of the limited access to public information, only a few studies could be conducted. Core [2] finds that the most important determinants of $\mathrm{D} \& \mathrm{O}$ insurance purchase are the risk of a lawsuit and the cost of financial distress by using a sample of 222 US firms whose fiscal year ended between 31 May 1994 and 31 December 1994. Core's findings are supported by O'Sullivan [3] who concludes that in the United Kingdom, D\&O insurance coverage and managerial share ownership are corporate governance instrument substitutes? Moreover, [3-5] suggest that D\&O insurance acts as a monitoring device. Most of them focus on the demand for D\&O insurance. This paper first examines the stock price reaction to first purchase announcement by using event study method. A significant stock price decline would suggest that investors stand against D\&O insurance purchase.

D\&O insurance might weaken the effectiveness of shareholder lawsuits as a D\&O control mechanism since directors and officers only must assume limited or no personal liability in suits by shareholders. Insurance also may reduce the degree of care exercised by D\&O. On the contrary, a significant stock price increase would suggest that investors value D\&O insurance purchase and think it is necessary to attract and maintain competent directors and officers. First, since directors and officers are not protected against personal liability, they may be overly conservative in managing the company. In today's business environment, directors and officers are required to take bold and innovative actions to keep companies competitive. Directors and officers cannot be expected to take such an action if left unprotected from shareholder suits. Second, there are still a lot of market mechanisms (e.g., the takeover market and human resource market) which act to force managers to work in the shareholders' interests, insurance may not have adverse incentive effects. Further, adverse incentive effects from insurance coverage are limited because of existing legal limits on insurance coverage and deductibles which must be paid by management. Finally, if there are reputation costs associated with losing suits, derivative suits may still be an important control device, even if all direct costs are paid by insurance.

This paper also examines whether market reactions are determined by the characteristics of the firm's corporate governance. By assessing the quality of the firm's corporate governance, insurers determine whether to insure a client or an insured firm's premiums, limits, and retentions. Therefore, these detailed disclosures of insured firms' D\&O policies will inform investors about the insurer's assessment of the quality of the firm's corporate governance and further cause investors to re- evaluate their assessment of the quality of the firm's corporate governance. Therefore, whether and how investors react to these disclosures is an open and interesting question. This paper examines the market reaction to a sample of 623 directors' and officers' insurance first purchase announced from 2002-2010 in Taiwan. This paper finds an economically and statistically significant negative stock price reaction over a 2-day window of approximately -0.870 percent (median-0.681). First, it indicates that detailed information in the D\&O insurance purchase disclosure affect investors' evaluation future company prospects as well as the risk/uncertainty of achieving them. This result also presents the evidence that disclosure of the details of D\&O insurance purchase policy is justified and valuable. Second, it indicates that on average shareholders in Taiwan view such insurance having adverse effects on their wealth.

This paper also conjectures that market reactions to the purchase of D\&O insurance are determined by the characteristics of the firm's corporate governance. This paper finds that more negative returns are associated with firms with more directors' compensations (option), firms whose stocks are more volatile, and firms whose litigation risks are higher. However, more positive reactions are associated with firms having higher debt. The contribution of this paper is to indicate that disclosure of the purchase of D\&O insurance, in addition to the characteristics of the firm's corporate governance, are critical in determining the market reaction to D\&O insurance purchase by firms. It indicates that detailed information in the D\&O insurance purchase disclosure affect investors' evaluation future company prospects as well as the risk/uncertainty of achieving them. Results of this paper also provide the evidence that mandatory disclosure of the details of D\&O insurance purchase policy, as is required in countries like UK and Canada, is justified and valuable.

Section 2: discusses previous literature on directors' and officers' insurance and develops hypotheses. Section 3: discusses the regression model and our test and control variables.

Section 4: describes our sample.

Section 5: provides the regression results.

Section 6: presents additional analyses, and

Section 7: contains concluding remarks.

\section{Literature Review and Hypotheses Development}

\section{Shareholder protection hypothesis}

Since shareholders are those that have the most to lose because of directors' and officers' incompetence or mismanagement and directors' and officers' incompetence or mismanagement is positively related to firm size. The shareholder protection hypothesis claims that it is them who should value D\&O insurance protection the most. In other words, the more shareholders must lose because of the directors' and officers' incompetence or mismanagement, the more positive they will react. The market value of equity would 
be the maximum possible loss that shareholders have to take. As the size of the possible loss increases, more protection becomes needed. If the shareholder protection hypothesis is correct, we should see a positive relationship between a corporation's market value of equity and the purchase of D\&O insurance protection. This paper uses the log of the market value of equity in millions of NT dollars (LnMVE) to measure the shareholders' wealth.

Another way to measure whether D\&O insurance protects the firm's providers of capital rather than its directors would be to look at the use of debt in the corporation's financial structure. As the level of debt is higher, it is less likely that any residual assets will be left to distribute to shareholders once a liquidation occurs. Shareholders should then value D\&O insurance as a tool to compensate them once a liquidation occurs due to directors' and officers' incompetence or mismanagement. There-fore this paper uses the book value of debt to the quasi-market value of assets to measure debtholder wealth in the corporation If shareholders value D\&O insurance as a wealth protection, we should see a positive relationship between D\&O insurance purchase and the use of debt in the corporation.

\section{Compensation package hypothesis}

Core [2] argues that D\&0 insurance is part of the directors' and officers' compensation package. There-fore directors and officers who already have better coverage should have to accept a smaller compensation. Moreover, firms with weaker corporate governance tend to have a larger compensation [5]. There-fore if shareholders view D\&O insurance as a part of the directors' and officers' compensation package and directors and officers overcompensate themselves due to weaker corporate governance, we should see a negative market reaction to $D \& 0$ insurance purchase. This paper uses three measures for directors' and officers' annual compensation: Cash, Options and Stock. Average annual cash compensation (in thousands of dollars) received by each board member, is computed as total cash compensation of the board divided by the number of board members.

Similarly, the average option compensation (in thousands of dollars) is calculated as the number of options per board members multiplied by the stock volatility and the stock price at the end of the year. The Stock variable gives this paper a measure of each board member's involvement in the corporation. By following Tufano's [6] measurement of CEO's wealth involvement in the corporation, this paper measures Stock the one-year variation in the average board member's wealth in shares of the corporation.

\section{Risk aversion hypothesis}

Unlike officers who sit on boards, also known as inside directors, receive other forms of compensation and benefits from the corporation, independent directors receive nothing material but reputation. Unless independent directors are offered with better and more complete protection, they will tend to be risk aversive, have no incentive to monitor, and even reject sitting on boards. As a result, if the director risk aversion hypothesis is correct, we expect the number of independent directors (Outsider) on a corporate board to be positively associated with a higher level of protection due to the D\&O insurance purchase. The more independent board of directors is, the more effective it is as a whole [7]. The more shareholders will benefit from bringing in more independent directors, the more positive they will react. This paper defines a director to be independent if he/she is not an officer of the corporation, related to an insider, nor a former employee.

\section{Entrenchment hypothesis}

According to [1,2] entrenched directors and officers may use their power on the board to purchase more D\&O insurance to extract wealth from shareholders without too much fear of reprisal. There-fore if shareholders view D\&O insurance as a wealthextraction by entrenched directors and officers, they are expected to act negatively to the purchase of $D \& O$ insurance. This paper uses the wealth of insiders (In wealth) on the corporate board to measure the intensity of entrenchment. In wealth is defined as the total number of shares held by insiders who sit on the board divided by the total number of shares.

\section{Signalling hypothesis}

The adverse selection literature predicts that firms with better monitored directors and officers will signal their better corporate governance quality by having less insurance [8]. In other words, firms with weaker corporate governance tend to purchase D\&O insurance. Moreover, signalling is even more important when directors' or officers' performance is harder to assess because their tasks are complex. Therefore, directors and officers in complex corporations have stronger incentive to signal since they benefit more from signalling their quality than directors and officers in other types of corporations. This paper uses the corporation's stock return volatility (Volatility) to measure firms' complexity. Directors and officers in corporation whose stock is very volatile are more likely to signal their quality through not purchasing D\&O insurance. Shareholders in such complex firms are expected to react more negatively if D\&O insurance was purchased.

\section{Litigation risk hypothesis}

One last determinant of market reaction to D\&O insurance purchase is the perceived litigation risk a corporation face. Through strategic corporate choices, a firm may increase its risk of being sued even though corporate directors and officers have done nothing wrong. Sometimes, the environment is simply more litigious. A firm with weaker governance will make this situation worse since shareholders are not able to impose tight control on directors' and officers' misbehaviours which are subsequently revealed to be inconsistent with the shareholders' interests. Therefore, the purchase of D\&O insurance reflects a corporation's perception of litigation risk they will face in the future. The higher risk they perceive, the stronger incentive they decide to purchase D\&O insurance. Shareholders in such high litigation risk firms are expected to react more negatively if D\&O insurance purchased.

Core [2] suggest that corporations are the most likely to be sued if they engage in mergers, acquisitions and divestiture, so that 
increased litigation risk should be a function of large variations in the corporation's book value of assets. This paper first calculates the log of the book value of assets (in millions of dollars). Then this paper uses the indicator Acquirer to indicate that if the log of the book value of assets has increased by more than $25 \%$ over the previous year; otherwise, 0 . Another indicator Divestor, on the other hand, is defined as if the log of the book value of assets has decreased by more than $25 \%$ over the previous year; otherwise, 0 . An increase in the litigation risk increases the frequency and the severity of lawsuits, so that we should expect an increase in the deductible and in the policy limit.

\section{Materials and Methods}

\section{Sample}

Table 1: Sample selection process

\begin{tabular}{|c|c|}
\hline \multicolumn{2}{|c|}{ Panel A: Sample selection process } \\
\hline Criteria & $\mathbf{n}$ \\
\hline Initial observations a & 1,797 \\
\hline Less: not first-year purchase disclosure & $-1,106$ \\
\hline Missing returns data & -68 \\
\hline & 623 \\
\hline Proxy statement information unavailable & -11 \\
\hline Final sample & 612 \\
\hline
\end{tabular}

\begin{tabular}{|c|c|c|}
\hline \multicolumn{3}{|c|}{$\begin{array}{c}\text { Panel B: Years in which our sample firms made their D\&O } \\
\text { insurance first-year purchase }\end{array}$} \\
\hline Year & Number of firms & \% of sample \\
\hline 2006 & 1 & $0.20 \%$ \\
\hline 2007 & 121 & $19.40 \%$ \\
\hline 2008 & 452 & $72.60 \%$ \\
\hline 2009 & 49 & $7.90 \%$ \\
\hline & 623 & $100.00 \%$ \\
\hline
\end{tabular}

a. The initial sample consists of 1,797 firm-year observations in which firms disclose they purchase D\&O insurance between 2002 and 2010 in the Taiwan Economic Journal (TEJ) database. Although sample collecting period starts from 2002 to 2010 , first sample is collected in 2006.

This paper identifies a D\&O insurance purchase disclosure sample by using public sources in the Taiwan Economic Journal (TEJ) database. Time period covers the 8-year period from 2002 through 2010. The reason for using 2002 is that this is the earliest year firms start to disclose whether they purchase the D\&O insurance or not. The initial sample consists of 1,797 firm-year observations in which firms disclose they purchase D\&O insurance between 2002 and 2010. In order to capture the initial market reactions to the disclosure of D\&O insurance first-year purchase, this paper deletes the D\&O insurance second, third or later year purchase disclosure samples. This paper also deletes observations without other financial information such as stock price, corporate governance. After imposing these restrictions, this paper has 617 firms' observations. Detailed sample selection process is presented in the Panel A of Table 1. In the Panel B of Table 1 this paper also provides a breakout of the number and percentage of sample observations across calendar years when firms made their D\&O insurance first-year purchase. 72.6 percent of D\&O insurance first- year purchases was made in 2008. It represents a plurality. This suggests that D\&O insurance purchase just have become trendy among publicly traded Taiwan firms in recent years.

\section{Regression model}

To explore the relation between returns and $D \& 0$ insurance purchase, this paper estimates a regression that includes D\&O insurance purchase and the firm's corporate governance characteristics. D\&O insurance purchases convey about changes in future company prospects as well as the risk/uncertainty of achieving them. Risk/uncertainly likely increases and prospects may well decrease when directors' and officers' competence and integrity are called into question. This paper proposes that a negative stock market reaction to $\mathrm{D} \& 0$ insurance purchase announcements is caused by declines in prospects (decreases in expected earnings) and/or increases in risk/uncertainty (increases in discount rates). On the contrary, a positive re-action to D\&O insurance purchase announcements is caused by increases in prospects (increases in expected earnings) and/or declines in risk/ uncertainty (decreases in discount rates). Empirical model of this paper can be summarized as follows:

CAR = $\mathrm{f}$ (LnMVE, Debt, Cash, Option and Stock, Outsider, In Wealth, Volatility, Acquirer, Divestor, and control variables)

\section{Discussion of control variables}

Monitoring substitutes: O’Sullivan [3], Holderness [4], Core [5] hypothesize that D\&O insurance is a substitute for board monitoring. There are two other important ways to monitor the board: blo ck holders and debtholders. If the monitoring hypothesis holds, it would be unnecessary to purchase D\&O insurance to bring in D\&O insurers as gatekeepers. Thus, in every case, this paper expects the impact to be negative if the monitoring hypothesis holds. The presence of creditors is measured using the previously defined Debt variable. If a D\&O insurer is the corporation's deep pocket in case of directors' and officers' incompetence, creditors may not need to monitor the wealth of the corporation as much. Regarding the Block holder variable, although one could make the argument that any block ownership may be a substitute for D\&O insurance monitoring, not every block holder will have incentive to exert influence on the board. Presumably, financial institution block holders are those who are more likely to be substitute for D\&O insurers' monitoring. Block holder is defined as the percentage of the shares held by financial institutions.

Financial distress: The way in which a corporation is financed should affect a corporation's overall risk, especially bankruptcy risk. Corporate insurance is demanded. For example, a corporation near bankruptcy will incur large financial distress costs. Moreover, since a bankrupt firm cannot honor its promise to financially support its managers' legal fees in the event of a lawsuit, the corporate indemnification plan becomes moot. As a result, corporate managers will require better protection to sit on boards of corporations near bankruptcy. Thus, bankruptcy risk should increase the need to purchase D\&O insurance. Financial distress 
also increases when the size of the corporate debt is relatively large. Therefore, the like li hood of bankruptcy is measured by following Core [2]. Core [2] measures the value of a put option on the corporation's assets with a strike price equal to the book value of debt to define the likelihood of bankruptcy.

In addition, a firm's past return may be a good indication of its financial health. Therefore, the higher the return the more liquidity the corporation must face a small market downturn. The need for D\&O insurance should therefore be smaller when past returns have been high. This paper uses the firm's return on assets to present profitability measure. ROA is defined as the ratio of net earnings

Table 2: Variable Definitions.

\begin{tabular}{|c|c|c|}
\hline Variable & Predicted Sign & Definition Experimental \\
\hline \multicolumn{3}{|l|}{ Experimental } \\
\hline LnMVE & + & The log of the market value of equity \\
\hline Debt & + & The book value (in thousands of dollars) of debt \\
\hline Cash & - & $\begin{array}{c}\text { Average annual cash compensation (in thousands of dollars) received by each } \\
\text { board member, is computed as total cash compensation of the board divided } \\
\text { by the number of boards }\end{array}$ \\
\hline Option & - & $\begin{array}{l}\text { Average option compensation (in thousands of dollars) is calculated as the } \\
\text { number of options per board members multiplied by the stock volatility and } \\
\text { the stock price at the end of the year }\end{array}$ \\
\hline Stock & - & $\begin{array}{l}\text { The one-year variation in the average board member's wealth in shares of the } \\
\text { corporation }\end{array}$ \\
\hline Out director & + & The number of independent directors on a corporate board \\
\hline \multirow[t]{2}{*}{ In Wealth } & & The total number of shares held by insiders who sit on the board \\
\hline & - & divided by the total number of shares \\
\hline Volatility & - & The corporation's stock return volatility \\
\hline Acquirer & - & 1 if the log of the book value of assets (in millions of dollars) has \\
\hline Variable & Predicted Sign & Definition \\
\hline Divestor & - & $\begin{array}{l}\text { increased by more than } 25 \% \text { over the previous year; otherwise, } 01 \text { if the log } \\
\text { of the book value of assets (in millions of dollars) has decreased by more than } \\
25 \% \text { over the previous year; otherwise, }\end{array}$ \\
\hline \multicolumn{3}{|l|}{ Control } \\
\hline Block holder & & The percentage of the shares held by financial institutions. \\
\hline ROA & & The ratio of net earnings to the book value of assets \\
\hline
\end{tabular}

\section{Calculation and description of abnormal returns}

This paper uses a market-adjusted model based on an equally weighted index (with dividends) to estimate abnormal returns. This model subtracts the TEJ market index return from a company's daily return to obtain the market-adjusted abnormal return (AR) for each day and company. The daily abnormal returns are summed to calculate the cumulative abnormal return (CAR) for a given time period. Table 3 provides descriptive statistics for the CARs over to the book value of assets. If one considers insurance as part of a corporation's overall risk management portfolio, then the corporate insurance hypothesis is probably the one that has received the most attention in the finance literature. Size should be an important determinant of a corporation's need for corporate insurance since larger corporations are better able to self-insure so that they have less need for insurance $[9,10]$ For example, large corporations may have an in-house litigation department that handles lawsuits. To measure the impact of size, this paper uses the previously defined variable Ln (MVE). Table 2 lists all the variables and their definitions and/or descriptions.

Table 3: Summary of mean abnormal returns for over four event windows surrounding D\&O insurance first purchase disclosures.

\begin{tabular}{|c|c|c|c|c|}
\hline \multicolumn{3}{|c|}{ Event windows } \\
\hline \multirow{2}{*}{ ARs (\%) } \\
\hline CARs (\%) \\
\hline (t-statistic) & -0.018 & -0.307 & -0.496 & -0.87 \\
\hline Standard deviation & -0.138 & $-2.265^{* * *}$ & $-4.026^{* * *}$ & $-3.092^{* * *}$ \\
\hline Min & 3.246 & 3.375 & 3.075 & 5.013 \\
\hline First quartile & -7.468 & -14.011 & -7.403 & -14.769 \\
\hline
\end{tabular}




\begin{tabular}{|c|c|c|c|c|}
\hline Median & 0.012 & -0.278 & -0.401 & -0.681 \\
\hline Third quartile & 1.641 & 1.308 & 0.981 & 1.577 \\
\hline Max & 7.186 & 7.284 & 7.124 & 14.408 \\
\hline (z-statistic) & 0.12 & $-2.604^{* * *}$ & $-3.566^{* * *}$ & $-1.963^{* *}$ \\
\hline
\end{tabular}

*Significant at the $10 \%$ level; ** Significant at the $5 \%$ level; ***Significant at the $1 \%$ level. Sample is 623 D\&O insurance first-year purchases disclosed from 2002 to 2010 in Taiwan. Market-adjusted CARs calculated using an equally weighted index.

Null hypothesis for each window is CAR = zero. T-tests are two tailed. Z-statistics are based on Wilcoxon signed ranks tests.

ARs on both days 0 and 1 are significantly negative (Table 3 ). So, the CAR over days $(0,1)$ is also significantly negative (mean $=-0.870$ percent, median $=-0.681$ percent $)$ and significantly less than zero ( $\mathrm{t}$-statistic $=-3.092, \mathrm{z}$-statistic $=-1.963)$. The abnormal reaction at the 75 percent quartile for all windows is slightly positive, indicating a few positive CARs surrounding D\&O insurance firstyear purchases disclosed. Indeed, 0.417 percent (260 of 623) of all day $(0,1)$ CARs are non-negative.

\section{Regression results and Discussion}

\section{Regression results}

Results of the OLS regression model for the sample are shown in Table 4. The sample regression model is significant (F-statistic=
1.878 , adjusted $\mathrm{R} 2=2$ percent). The regression results are consistent with the results in the univariate tests (not tabled). This paper finds that the Debt variable coefficient is significant and positive in the regression analysis $(\mathrm{t}=2.061)$. Shareholder protection hypothesis is supported. Since shareholders value D\&O insurance as their wealth protection, this paper finds a positive relationship between D\&O insurance purchase and the use of debt in the corporation. On the contrary, the Option variable coefficient is highly significant and negative in the regression analysis $(\mathrm{t}=-3.461)$. Compensation package hypothesis is supported. Since shareholders view D\&O insurance as a part of the directors' and officers' compensation package and just only use to overcompensate D\&O themselves, this paper finds a negative market relationship between D\&O insurance purchase and the use of Option in the corporation.

Table 4: OLS regression results for all sample D\&O insurance first-year purchases.

\begin{tabular}{|c|c|c|c|}
\hline Independent Variables & Predicted Sign & Coefficient & T-Statistic \\
\hline $\mathrm{C}$ & & 2.061 & 0.865 \\
\hline \multicolumn{4}{|c|}{ Shareholder protection hypothesis } \\
\hline LnMVE & + & -0.089 & -0.528 \\
\hline Debt & + & 0 & $2.061^{* *}$ \\
\hline \multicolumn{4}{|c|}{ Compensation package hypothesis } \\
\hline Cash & - & 0 & -1.474 \\
\hline Option & - & 0 & $-3.461^{* * *}$ \\
\hline Stock & - & -0.928 & -0.406 \\
\hline \multicolumn{4}{|c|}{ Risk aversion hypothesis } \\
\hline Out director & + & -0.096 & -0.713 \\
\hline \multicolumn{4}{|c|}{ Entrenchment hypothesis } \\
\hline In Wealth & - & -1.655 & -0.448 \\
\hline \multicolumn{4}{|l|}{ Signaling hypothesis } \\
\hline Volatility & - & -1.059 & $-2.112^{* *}$ \\
\hline \multicolumn{4}{|l|}{ Litigation risk hypothesis } \\
\hline Acquiror & - & -0.908 & $-1.658^{*}$ \\
\hline Independent Variables & Predicted sign & Coefficient & t-Statistic \\
\hline Divestor & - & -0.485 & -0.428 \\
\hline \multicolumn{4}{|l|}{ Control } \\
\hline Block holder & & -0.791 & -0.184 \\
\hline ROA & & 1.568 & 0.761 \\
\hline \multicolumn{4}{|c|}{ Model statistics n } \\
\hline & & & 612 \\
\hline Adjusted R2 & & & $2 \%$ \\
\hline F-statistic & & & $1.878^{* *}$ \\
\hline
\end{tabular}

Significant at the $10 \%$ level; **Significant at the $5 \%$ level; ${ }^{* * *}$ Significant at the $1 \%$ level. Market-adjusted CARs calculated using an equally weighted index. 
The Volatility variable coefficient is also highly significant and negative in the regression analysis $(\mathrm{t}=-2.112)$. Signalling hypothesis is supported. Since directors and officers in corporation whose stock is very volatile are more likely to signal their better governance quality through not purchasing D\&O insurance. Shareholders in such complex firms are expected to react more negatively if $\mathrm{D} \& O$ insurance was purchased The Acquirer variable coefficient is highly significant and negative in the regression analysis $(t=-1.658)$. Litigation risk hypothesis is supported. Since increased litigation risk should be a function of large variations in the corporation's book value of assets. Shareholders in such high litigation risk firms are expected to react more negatively if D\&O insurance purchased.

\section{Conclusion}

The purpose of this paper is to assess whether the purchase and detailed disclosures of insured firms' D\&0 policies are valued from investors' (or shareholders') standpoints. Specifically, this paper examines the stock price reaction to first purchase announcement by using event study method and whether market reactions are determined by the characteristics of the firm's corporate governance. This study finds that on average shareholders in Taiwan view such insurance to have adverse effects on their wealth. Four determinants are found to affect market reactions. The result of this paper support shareholder protection hypothesis, compensation package hypothesis, signalling hypothesis, and litigation risk hypothesis. The contribution of this paper is to indicate that disclosure of the purchase of D\&O insurance, in addition to the characteristics of the firm's corporate governance, are critical in determining the market reaction to $\mathrm{D} \& 0$ insurance purchase by firms. It indicates that detailed information in the D\&O insurance purchase disclosure affect investors' evaluation future company prospects as well as the risk/uncertainty of achieving them. Results of this paper also provide the evidence that mandatory disclosure of the details of D\&O insurance purchase policy, as is required in countries like UK and Canada, is justified and valuable.

\section{Acknowledgement}

I thank Research Interaction Forum Session participants at the 2011 Annual Meeting of the American Accounting Association for their helpful comments.

\section{Conflict of Interest}

No conflict of interest.

\section{References}

1. Chalmers J, Dann L, Harford J (2002) Managerial opportunism? Evidence from Directors and Officers Insurance Purchases. Journal of Finance 57(2): 609-636.

2. Core JE (1997) On the Corporate Demand for Directors and Officers Insurance. Journal of Risk and Insurance 64(1): 63-87.

3. O Sullivan N (1997) Insuring the Agents: The role of Directors and Officers Insurance in Corporate Governance. Journal of Risk and Insurance 64(3): 545-556.

4. Holderness CG (1990) Liability Insurers as Corporate Monitors. International Review of Law and Economics 10(2): 115-129.

5. Core JE (2000) The Directors and Officers Insurance Premium: An Outside Assessment of the Quality of Corporate Governance. Journal of Law Economics and Organization 16(2): 449-477.

6. Tufano P (1996) Who Manages Risk? An Empirical Examination of Risk Management Practices in the Gold Mining Industry. Journal of Finance 4: 1097-137.

7. Jensen MC (1993) The Modern Industrial Revolution, Exit, and Failure of Internal Control Systems. Journal of Finance 48(3): 831-880.

8. Rothschild M, Stiglitz J (1976) Equilibrium in Competitive Insurance Markets: An Essay on the Economics of Imperfect Information. Quarterly Journal of Economics 90: 629-649.

9. Mayers D, Smith CW (1990) On the Corporate Demand for Insurance: Evidence from the Reinsurance Market. Journal of Business 63(1): 1940.

10. Smith CW, Stulz RM (1985) The Determinants of Firms' Hedging Policies. Journal of Financial and Quantitative Analysis 19: 127-140. 